\title{
STRATEGI OPTIMASI PEMANFAATAN SUMBER AIR BANTAR AWI SUNGAI CIKAPUNDUNG TERHADAP INSTALASI PENGOLAHAN AIR MINUM DAGO PAKAR
}

\author{
Evi Afiatun*, Sri Wahyuni, Styvani Merinda \\ Program Studi Teknik Lingkungan, Universitas Pasundan
}

\begin{abstract}
Abstrak
Cikapundung merupakan salah satu sungai yang digunakan oleh PDAM Kota Bandung sebagai sumber air baku. Penurunan kualitas air yang terjadi di Sungai Cikapundung merupakan salah satu alasan mengapa perlu untuk mengevaluasi kinerja Instalasi Pengolahan Air Minum ( IPAM ) Dago Pakar . Tingginya tingkat pencemaran pada sumber air baku ini disebabkan oleh masih banyaknya warga masyarakat yang membuang sampah dan kotoran hewan ternak ke sungai juga erosi. Dengan kondisi tersebut IPAM Dago Pakar mencoba untuk mengolah air baku ini agar dapat menghasilkan air bersih yang layak dikonsumsi oleh masyarakat dan sesuai dengan standar yang berlaku yaitu Peraturan Menteri 492/MENKES/PER/IV/2010. Metoda penelitian dilakukan dengan cara menghitung rata-rata debit dari BBWS dan IPAM Dago Pakar, mengevaluasi kinerja IPAM berdasarkan evaluasi pada air hasil olahan yang dihasilkan serta evaluasi terhadap kriteria desain bangunan unit pengolahan. Berdasarkan observasi dan studi pustaka, dapat disimpulkan antara lain IPAM Dago Pakar memiliki satu (1) seri pengolahan air lengkap, yang terdiri dari intake, pra-sedimentasi, koagulasi, flokulasi, sedimentasi, filtrasi, desinfeksidan reservoir, (2) total kapasitas IPAM Dago Pakar adalah sebesar 600 L/detik, (3) pada musim penghujan, proses backwash bisa dilakukan hingga 3-5× 1 hari/unit untuk itu disarankan pihak PDAM membangun sebuah bak penampungan air hasil backwash agar dapat dipompakan kembali ke unit koagulasi untuk diolah kembali, (4) berdasarkan pengamatan dan data yang diperoleh, sumber air baku (sungai Cikapundung, Bantar Awi) masih memenuhi standar kualitas air baku untuk air minum, Peraturan Pemerintah No. 82, 2001 meskipun terdapat beberapa parameter yang terkadang tidak memenuhi baku mutu salah satunya adalah residu tersuspensi, namun setelah melewati proses pengolahan air yang diproduksi sudah memenuhi baku mutu, (5) berdasarkan kesesuaian pada criteria desain, maka bak prasedimentasi membutuhkan penambahan waktu detensi dan pelebaran agar kinerja unit prasedimentasi ini bisa lebih dioptimalkan dalam mengatasi fluktuasi ke keruhan air bakupadasaatmusimpenghujan.
\end{abstract}

Kata kunci: air baku, air bersih, evaluasi, kinerja, prasedimentasi, kekeruhan, bakumutu

\section{Pendahuluan}

Dalam segala aktivitasnya, manusia memerlukan air sebagai sumber daya alam, terutama sebagai air bersih (Anggraini, Samadi, \& Warnadi, Sept 2013). Pertambahan jumlah penduduk dan peningkatan aktivitas ekonomi di masyarakat menimbulkan desakan kebutuhan air yang

\footnotetext{
${ }^{*}$ Penulis Korespondensi:

E-mail: eviafiatun@unpas.ac.id
}

Diterima pertama kali: 29 April 2018

Direvisi : 16 Agustus 2018

Disetujui untuk publikasi: 25 Agustus 2018 semakin banyak, sementara keberadaan sumber air bersih saat ini dirasakan semakin terbatas.

Keterbatasan ini semakin dirasakan karena semakin tingginya kompetisi dalam penggunaan air bersih, sementara usaha yang dilakukan untuk pemenuhan kebutuhan air bersih ini dirasakan belum cukup karena masih belum semua masyarakat bisa dengan mudah menikmati air bersih. Ditambah lagi dengan penurunan kualitas air yang belakangan menjadi masalah tambahan dalam penyediaan air bersih baik di kota maupun di daerah-daerah terpencil. 
Penurunan kualitas air ini dapat disebabkan karena sistem pengolahan air yang sudah ada mengalami penurunan kinerja dalam usaha mengolah sumber air baku atau penurunan kualitas air ini juga bisa disebabkan oleh penurunan kualitas air baku yang digunakan, misalnya sumber air yang digunakan adalah air permukaan dan mengalami penyurutan atau kekeruhan air meningkat akibat terjadinya erosi, meningkatnya volume sampah pada badan air dan banyak kemungkinan lain yang terjadi pada badan air yang digunakan.

Air yang layak diminum adalah air yang memenuhi standar baku mutu menurut PERMENKES RI No. 492/MENKES/IV/2010 tentang "Persyaratan Kualitas Air Minum". Parameter-parameter yang harus dilihat yaitu parameter fisik, kimiawi dan bakteriologis, dan parameter tersebut merupakan satu kesatuan. Jadi jika ada satu saja parameter yang tidak memenuhi syarat maka air tesebut tidak layak untuk diminum. Pemakaian air minum yang tidak memenuhi standar kualitas tersebut dapat menimbulkan gangguan kesehatan, baik secara langsung maupun tidak langsung.

Kegiatan penggunaan air bersih ini merupakan kegiatan yang berlangsung secara terus menerus dan untuk jangka waktu yang panjang. Karena itu sistem penyediaan air bersih yang dirancang harus merupakan sistem yang berkesinambungan dan pengoperasiannya untuk jangka waktu panjang maka dibutuhkan sumber air yang harus terjaga kualitas, kuantitas dan kontinuitasnya, standar kualitas air baku berpedoman pada Peraturan Pemerintah No. 82 Tahun 2001. Dengan hal ini diharapkan kebutuhan masyarakat akan air bersih dan higienis dapat terpenuhi.

Maksud dari penelitian ini adalah untuk menyusun strategi optimasi kualitas dan kuantitas sumber air terhadap kinerja instalasi pengolahan air minum guna mengoptimalkan kapasitas produksi. Tujuan dari penelitian ini adalah untuk mengoptimalkan kinerja instalasi pengolahan air minum Dago Pakar.

\section{Kondisi Eksisting}

\section{DAS Cikapundung}

Sungai Cikapundung, sungai sepanjang 28 kilometer ini, melintasi 11 kecamatan di tiga kabupaten kota, yaitu Kota Bandung, Kabupaten Bandung dan Kabupaten Bandung Baratdengan lebar sungai di hulu 22 meter dan di hilir 26 meter. Daerah hulu Sungai Cikapundung terletak di daerah Cigulung dan Cikapundung, Maribaya, (Kab. Bandung Barat). Sedangkan bagian tengah termasuk Cikapundung Gandok dan Cikapundung Pasirluyu (Kota Bandung).

Sungai Cikapundung bermuara di Sungai Citarum di Bale Endah (Kab.Bandung) dan menjadi salah satu dari 13 anak sungai utama yang memasok air untuk Sungai Citarum.Daerah aliran sungai (DAS) Cikapundung meliputi wilayah seluas 15.386,5 hektar dengan wilayah administrasi Kabupaten Bandung Barat, Kota Bandung, dan Kabupaten Bandung.

Sungai Cikapundung mengalir dari mata air Batununggal di utara Maribaya. Sungai Cikapundung merupakan sungai terbesar yang melalui Kota Bandung, sungai ini memiliki beberapa anak sungai, yaitu Sungai Cikukang, Sungai Cigulug, Sungai Cikawari dan Sungai Cikapundung Kolot, namun selain anak sungai yang telah disebutkan di atas masih terdapat dua anak sungai kecil lainnya yang berfungsi sebagai saluran drainase kota, anak sungai ini yaitu Sungai Cipaganti dan Cipalasari.

Secara umum, pemanfaatan air Sungai Cikapundung adalah untuk keperluan air minum (PDAM Dago Pakar dan PDAM Badak Singa), PLTA (Pakar dan Cibengkok), penggelontoran dan irigasi. Konfigurasi penggunaan air secara skematik di sepanjang Sungai Cikapundung dari hulu sampai bermuara di Citarum Hulu dapat dilihat pada gambar di bawah ini 


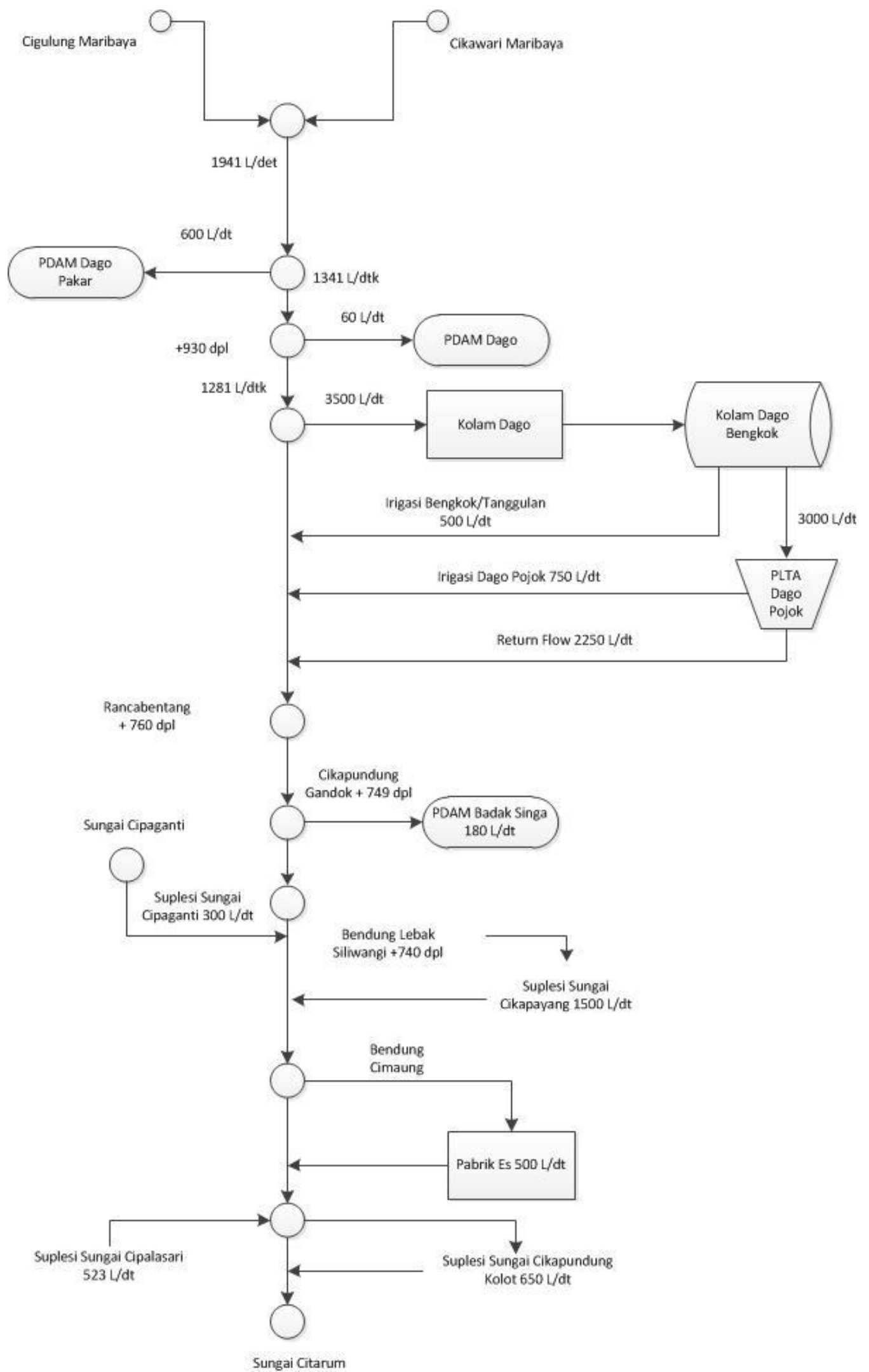

Gambar 1. Skematik Penggunaan Air Sungai Cikapundung 


\section{Kondisi Eksisting IPAM Dago Pakar}

Pada umumnya rangkaian bangunan pengolahan air minum dan teknologi yang diterapkan pada suatu instalasi pengolahan air minum tergantung pada kualitas air baku dan hasil akhir dari proses pengolahan air baku yang diinginkan (sesuai dengan standar baku mutu air minum). Sebuah bangunan pengolahan air minum terdiri atas beberapa unit operasi dan unit proses. Unit operasi dan unit proses merupakan suatu unit yang mengolah air minum secara fisik dan kimia tergantung kepada kegunaannya.

Rangkaian pengolahan yang dilakukan di IPAM Dago Pakar terdiri dari proses penyaringan awal, prasedimentasi, koagulasi, flokulasi, sedimentasi, filtrasi, dan desinfeksi. Air yang telah diolah digunakan untuk menyuplai Reservoir XII dengan kapasitas $7.500 \mathrm{~m}^{3}$, reservoir XII ini berlokasi di jalan Ir. H. Juanda.

Sumber air baku yang digunakan oleh Instalasi Pengolahan Air Minum (IPAM) Dago Pakar merupakan air permukaan yang diambil dari sungai Cikapundung tepatnya di daerah Bantar Awi, sehingga air dialirkan secara gravitasi ke instalasi pengolahan. Instalasi Pengolahan Air Minum (IPAM) ini bertempat di jalan Dago Pakar Barat.

\section{Evaluasi dan Pembahasan}

Secara umum sumber air Bantar Awi ini masih memenuhi kriteria persyaratan untuk dijadikan sumber air baku meskipun dalam pemeriksaan yang dilakukan oleh PDAM terdapat beberapa parameter yang tidak memenuhi baku mutu, namun kuantitas dari air baku ini sendiri justru terlihat menurun, sementara itu kinerja IPAM Dago Pakar ini sudah baik, namun demikian terdapat beberapa permasalahan yang ditemukan pada saat observasi langsung, baik itu permasalahan operasional maupun pemeliharaan unit pengolahan yang menyebabkan pengolahan air baku menjadi kurang sempurna.
Evaluasi dan Pembahasan Kondisi Sumber Air Bantar Awi

Sungai Cikapundung kawasan Bantar Awi merupakan sumber air baku yang digunakan oleh IPAM Dago Pakar. Tngginya tingkat kebutuhan akan air bersih justru berbanding terbalik dengan menurunnya pasokan air juga kualitas dari sumber air yang dimanfaatkan, maka dilakukanlah proses evaluasi pada sumber air Bantar Awi, dengan adanya evaluasi ini maka dapat diketahui permasalahan yang ada pada sumber air untuk selanjutnya dicari solusi dari permasalahan yang dihadapi. Evaluasi ini dilakukan terhadap kondisi eksisting sumber air yang meliputi evaluasi terhadap fluktuasi debit dan kualitas sumber air guna mengetahui apakah sumber air ini masih layak digunakan sebagai air baku dari PDAM dan apakah sumber air ini masih bisa memenuhi kebutuhan pasokan air baku untuk PDAM.

Evaluasi Pengukuran Debit Pengambilan Air Baku dan Debit Air Hasil Olahan Pada Intake di Sungai Cikapundung Kawasan Bantar Awi oleh PDAM Tirtawening

Berdasarkan hasil pengukuran debit harian yang dilakukan di intake Bantar Awi yang dilakukan dari Januari-Juli 2013 didapat nilai debit ratarata untuk air baku sebesar $595 \mathrm{~L} /$ det sementara debit air hasil olahannya sebesar 559,33 L/det. Hasil yang didapatkan dari pengukuran debit ini masih memiliki selisih sebesar $5 \mathrm{~L} /$ det dari besarnya debit yang diizinkan untuk dimanfaatkan sebagai sumber air baku, yaitu sebesar 600 L/det. Fluktuasi debit yang meskipun tidak terlalu signifikan ini disebabkan oleh intensitas hujan yang variatif disetiap bulannya.

Berdasarkan SIPPA yang dimiliki oleh PDAM, debit air yang diizinkan untuk diambil pada musim penghujan adalah sebesar $600 \mathrm{~L} /$ atau setara dengan $1.555 .200 \mathrm{~m}^{3} / \mathrm{bln}$ dan $120 \mathrm{~L} / \mathrm{det}$ 
pada musim kemarau atau setara dengan $311.040 \mathrm{~m}^{3} / \mathrm{bln}$.

\section{Evaluasi dan Pembahasan Kualitas Sumber Air Bantar Awi}

Pemeriksaan harian kualitas air baku ini meliputi pemeriksaan terhadap nilai kekeruhan dan $\mathrm{pH}$. Berdasarkan hasil pemeriksaan yang telah dilakukan, terlihat nilai kekeruhan rata-rata tertingginya adalah 924,28 NTU yang terjadi pada bulan April dengan nilai kekeruhan tertingginya adalah 5202 NTU, sementara nilai kekeruhan rata-rata terendahnya adalah 200,59 NTU yang terjadi pada bulan Juli lalu dengan nilai kekeruhan terendahnya adalah 63,2 NTU. Sementara itu nilai $\mathrm{pH}$ untuk air baku sendiri relatif stabil yaitu 7,10 .

Kekeruhan sumber air Bantar Awi ini sangat dipengaruhi oleh curah hujan yang berbeda-beda setiap bulannya. Hujan di hulu sungai membawa banyak partikel-partikel lumpur dari erosi sungai, pasir dan sisa-sisa tumbuhan tak jarang kotoran ternak juga turut mempengaruhi kekeruhan dari badan air ini. Namun tingginya nilai turbiditas pada air baku ini masih dapat diatasi dengan adanya bak prasedimentasi pada rangkaian unit pengolahan pada IPAM Dago pakar dan dibantu dengan pembubuhan dosis koagulan pada proses pengolahan air minum.

Pada pemeriksaan tiga bulanan, standar kualitas air baku berpedoman pada Peraturan Pemerintah No. 82 Tahun 2001. Berdasarkan pemeriksaan kualitas air baku yang dilakukan pada bulan April, Juni, September, Desember 2012 dan Maret 2013 terdapat 12 parameter yang tidak memenuhi baku mutu, parameter tersebut antara lain; Residu Tersuspensi, $\mathrm{BOD}_{5}$, COD, Fluorida (F), Total Fosfat sebagai P, Khlorida Bebas, Mangan (Mn), Nitrit sebagai N, DO, Total Coliform dan Fecal Coliform.

\section{Evaluasi dan Pembahasan Kinerja IPAM Dago Pakar}

Evaluasi terhadap unit-unit pengolahan air ini dilakukan untuk mengetahui sejauh mana kinerja unit-unit ini saat beroperasi. Kinerja ini tentu saja disesuaikan dengan instruksi kerja dan kuantitas juga kualitas air hasil olahan. Dengan adanya evaluasi maka dapat diketahui permasalahan yang ada pada sumber air maupun pada instalasi untuk selanjutnya dicari solusi dari permasalahan yang dihadapi.

Di bawah ini adalah hasil evaluasi terhadap unit Intake di Bantar Awi :

1) Tidak adanya saringan pasir halus (fine screen) sehingga sampah-sampah yang halus dan pasir dengan ukuran kurang dari $1 \mathrm{~cm}$, masih dapat lolos ke bak prasedimentasi bahkan sampai ke IPAM Dago Pakar.

2) Terdapat peralatan saringan sampah mekanik (mechanical screen) dibangunan intake ke-2, namun sudah lama rusak akibat sering mengangkat sampah yang berat dan sulit diangkat, seperti batu-batu dan kayu-kayu yang masuk ke mulut intake.

Berikut ini adalah hasil evaluasi terhadap unit Prasedimentasi di Bantar Awi :

1) Waku detensi bak prasedimentasi sangat kecil jika dibandingkan dengan kriteria desain pada umumnya, yaitu 5 menit berbanding 0,5 - 3 jam.

2) Bangunan prasedimentasi hanya mampu mengendapkan pasir saja, namun lumpur yang terkandung dalam air baku tidak turut terendapkan secara optimal dan masih terbawa sampai pengolahan selanjutnya.

3) Disarankan untuk melalukan rekonstruksi terhadap unit ini, saran ini diberikan karena dilihat dari lokasi unit masih mendukung untuk dilakukannya rekonstruksi berupa pelebaran unit beberapa meter, agar kinerja dari unit ini bisa semakin optimal. 
4) Pengurasan lumpur tidak tuntas hanya dengan membuka katup penguras saja, namun harus tetap dilakukan pengurasan pada bak.

5) Pada saat banjir, pengurasan lumpur bisa dilakukan hingga 3 kali dalam sehari sehingga akan mengganggu debit yang masuk ke instalasi pengolahan.

6) Pada saat banjir besar, sampah menyumbat bar screen sehingga mengurangi debit air yang masuk ke pipa transmisi secara signifikan.

7) Sampah masih ada yang lolos hingga ke instalasi pengolahan.

Berdasarkan hasil pemantauan terhadap kekeruhan pada unit Koagulasi yang dilakukan dari Januari - Juli 2013 maka terlihat persentase penurunan nilai kekeruhan yang cukup besar yaitu lebih dari $90 \%$ setelah adanya pembubuhan koagulan pada proses koagulasi. Untuk mendapatkan dosis pembubuhan koagulan dilakukan jartest di laboratorium IPAM Dago Pakar. Jartest adalah proses penentuan dosis koagulan optimum (Oktaviasari \& Mashuri, 2016). Dari hasil jartest inilah dapat diketahui dosis optimal untuk pembentukan flok.

Pada kenyataannya pembubuhan koagulan hanya diberikan melalui selang plastik dan hanya pada 1 titik saja, sehingga pencampuran koagulan dengan air baku kurang merata. Pembubuhan akan lebih optimal apabila proses pembubuhannya dilakukan dengan menggunakan pipa perforated yang diletakkan sejejar dengan ambang/weir, sehinggan koagulan akan menetes disepanjang ambang/weir sehingga pencampurannya akan lebih merata.

Waktu detensi unit flokulasi terlalu cepat yaitu 12 menit, dengan kondisi ini masing-masing kompartemen mengalami perubahan gradient kecepatan yang secara hidrolis dapat menyebabkan penurunan gradien kecepatan tidak secara teratur sehingga sering menyebabkan terjadinya turbulensi dan flok akan kembali pecah. Untuk mengantisipasi tidak terjadinya perubahan gradient kecepatan yang tiba-tiba akibat aliran melalui celah bukaan antar kompartemen dan belokan, maka diperlukan adanya "Insert Flocculator" berupa sekat-sekat pengarah aliran yang berfungsi untuk meratakan penurunan gradien kecepatan.

Beberapa permasalahan teknis yang terjadi pada unit sedimentasi antara lain;

1) Pada saluran inlet sedimentasi, terdapat slot slot yang membagi aliran masuk melalui celah plate settler, sering terhambat alirannya oleh lumpur dan sampah yang ikut masuk.

2) Otomatisasi buka tutup katup penguras lumpur sudah tidak dapat bekerja disebabkan masalh rubber ring/gasket karena unit pneumaticnya aus/rusak

Di bawah ini adalah hasil evaluasi terhadap unit Filtrasi di IPAM Dago Pakar :

1) Beberapa valve inlet bocor, sehingga pada saat pencucian aliran air dari bak sedimentasi tetap masuk menyebabkan tambahan kehilangan air.

2) Kerusakan pada proses otomatisasi pencucian filter hal ini disebabkan karena adanya kebocoran udara pada penstock maupun unit lainnya yang diakibatkan oleh rusak/ausnya rubber ring /gasket.

Dari evaluasi yang dilakukan terhadap unit desinfeksi, terdapat kerusakan alarm dan alat deteksi kebocoran gas khlor rusak, sehingga kebocoran seringkali tidak terdeteksi, selain itu kebersihan ruangan penyimpanan tangki kurang terjaga dengan baik.

Pada unit clear well tidak terdapat sarana untuk pengurasan sehingga endapan-endapan yang terdapat pada unit ini tidak dapat dibersihkan, namun kondisi unit ini masih dalam keadaan baik, sementara itu pada unit reservoir distribusi perawatan terhadapunit ini kurang baik, hal ini 
terlihat dari kurangnya waktu periode pembersihan.

Disarankan pihak PDAM melakukan pemeriksaan secara berkala terhadap keadaan unit ini, dikhawatirkan terjadi keretakan pada dinding bangunan yang dapat menyebabkan kebocoran. Sedangkan pada unit reservoir waktu pengurasan/pembersihan dari dirasa masih kurang karena hanya dilakukan 1 tahun sekali, akan lebih baik jika dilakukan setiap 6 bulan sekali, selain itu membersihkan lingkungan disekitar reservoir juga sebaiknya dilakukan karena banyaknya rerumputan yang tumbuh dapat menghambat proses pemantauan pada dinding reservoir.

\section{Strategi Optimasi}

Setelah melalukan evaluasi terhadap kualitas dan kuantitas air baku di Sungai Cikapundung Kawasan Bantar Awi dan evaluasi terhadap kinerja IPAM Dago Pakar, maka tahapan selanjutnya dari penelitian ini adalah penyusunan strategi optimalisasi pemanfaataan sumber air Bantar Awi terhadap kinerja dari IPAM Dago Pakar.

\section{Strategi Optimasi Kinerja IPAM}

Berdasarkan evaluasi yang telah dilakukan terhadap kualitas dan kuantitas Sungai Cikapundung Kawasan Bantar Awi sebagai air baku yang digunakan oleh PDAM, juga evaluasi terhadap kinerja IPAM Dago Pakar maka hasil dari evaluasi tersebut adalah debit air baku yang dipergunakan oleh IPAM Dago Pakar sudah memenuhi SIPPA yang berlaku, yaitu $600 \mathrm{~L} / \mathrm{dtk}$. Tingginya kekeruhan pada saat musim penghujan menyebabkan jumlah proses backwash yang harus dilakukan bertambah dan berpengaruh pada volume air hasil produksi yang tentu saja akan turut berkurang. Pada musim penghujan, proses backwash bisa dilakukan hingga 3-5x 1 hari/unit untuk itu disarankan pihak PDAM membangun sebuah bak penampungan air hasil backwash agar dapat dipompakan kembali ke unit koagulasi untuk diolah kembali.

Dari segi kualitas juga cukup baik, meskipun masih terdapat beberapa parameter yang terkadang tidak memenuhi baku mutu. Parameter tersebut antara lain adalah nilai BOD, COD, DO, kandungan bakteri Total Coliform dan Fecal Coliform. Dari beberapa parameter yang tidak terkadang tidak memenuhi baku mutu ini yang secara garis besar disebabkan oleh keadaan sungai yang sudah tercemar oleh kegiatan para penduduk di sekitar sungai itu sendiri maupun oleh penduduk yang berdomisili di hulu sungai Cikapundung, kegiatan tersebut meliputi kebiasaan penduduk yang masih terus membuang sampah, kotoran ternak maupun pakan ternak ke sungai. Untuk permasalahan ini diharapkan pihak PDAM dapat memberikan penyuluhan mengenai dampak dari kegiatan tersebut dan pengertian akan pentingnya menjaga kebersihan sungai karena aka nada banyak pihak yang dirugikan dari pencemaran yang dilakukan.

Hasil evaluasi terhadap kinerja IPAM Dago Pakar sudah cukup baik, karena setiap unit masih beroperasi dengan baik, meski pundi rasa masih perlu dilakukan perbaikan di beberapa unit untuk menunjang kinerja IPAM itu sendiri. Berangkat dari permasalahan mengenai fluktuasi kekeruhan pada air baku yang tak jarang melonjak tinggi melebihi 1000 NTU pada musim hujan maka disarankan pihak PDAM melakukan pelebaran pada bak Prasedimentasi di Bantar Awi, karena dilihat dari waktu detensi yang ada yaitu hanya 5 menit, kinerja unit ini belum memenuhi syarat dari kriteria desain yang seharusnya, unit prasedimentasi seharusnya memiliki waktu detensi sebesar 0,5-3 jam (Darmasetiawan, 2004).

Selain dari hasil pengukuran fluktuasi kekeruhan air baku yang melebihi 1000 NTU pada musim penghujan dilihat dari lokasi bak prasedimentasi di Bantar Awi yang juga masih memungkinkan 
untuk melakukan pelebaran, maka disarankan evaluasi pada sumber air baku maupun pada untuk melakukan pelebaran pada bak kinerja IPAM Dago Pakar.

prasedimentasi.

Di bawah ini pada Gambar 2 disajikan skema strategi optimasi yang disusun berdasarkan hasil

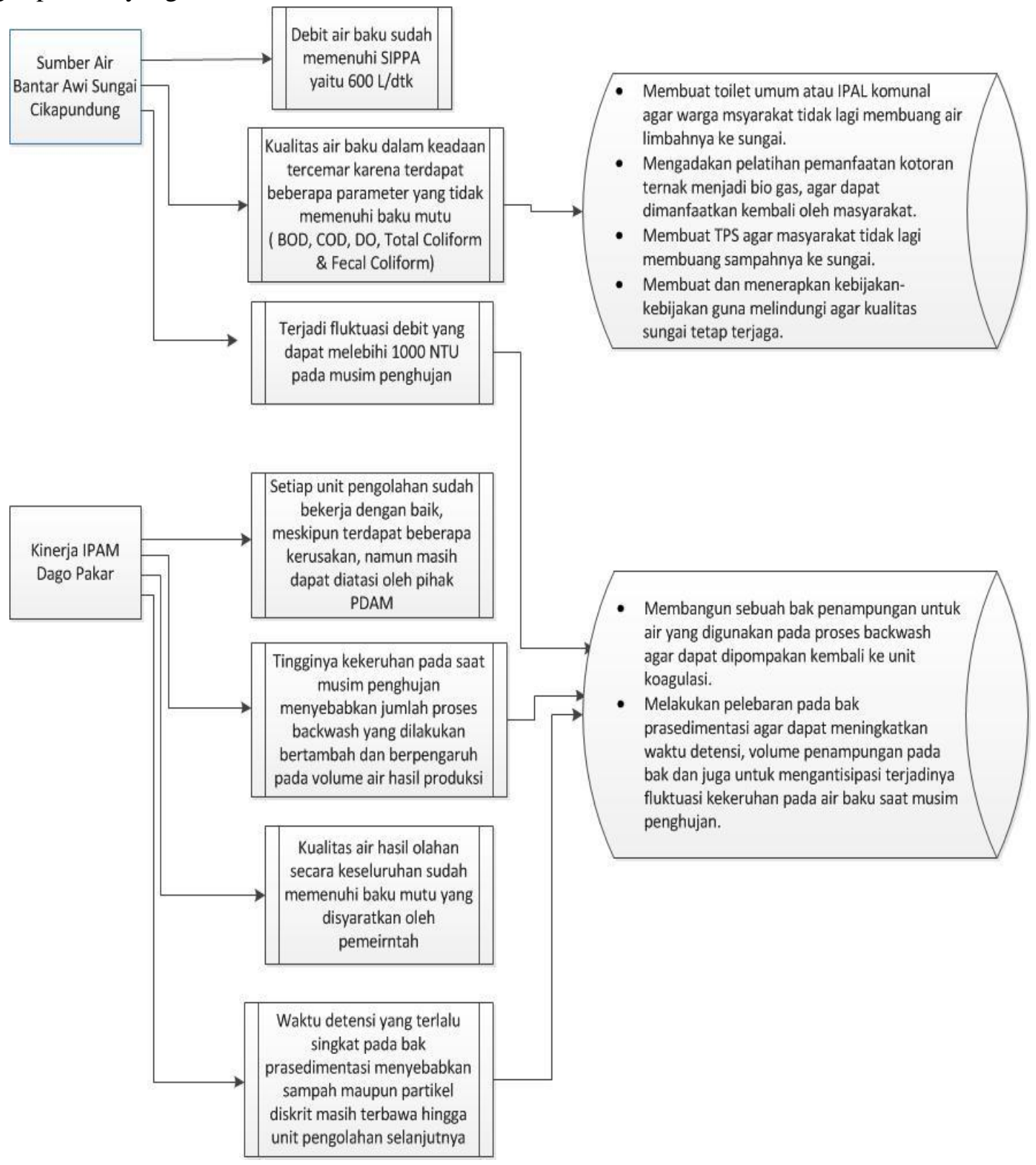

Gambar 2. SkemaStrategiOptimasiPemanfaatanSumber Air BantarAwiTerhadapKinerja IPAM Dago Pakar

Bak Prasedimentasi pada IPAM Dago Pakar terdiri dari 2 unit dan terletak sekitar $100 \mathrm{~m}$ dari bangunan sadap. Dimensi bangunan prasedimentasi $\mathrm{P} \times \mathrm{L} \times \mathrm{T}$ adalah $16 \mathrm{~m} \times 2 \mathrm{~m} \times 2,8 \mathrm{~m}$ sehingga volume totalnya adalah $180 \mathrm{~m}^{3}$. Jika debit yang masuk sebanyak 600 L/dtk maka waktu detensinya adalah 5 menit.Apabila dibandingkan dengan kriteria desain yang ada, 
maka seharusnya bak prasedimentasi memiliki waktu detensi sebesar 0,5-3 jam, untuk saat ini waktu detensi yang ada belum memenuhi kriteria desain, makadari itu penulis menyarankan untuk melakukan penambahan lebar pada dimensi bak prasedimentasi, berikut ini adalah perhitungan dimensi baru untuk bak prasedimentasi.

Kondisi Eksisting Prasedimentasi IPAM Dago Pakar

$\mathrm{Q}=600 \mathrm{~L} / \mathrm{dtk}$

Dimensi Bak: $\mathrm{P} \times \mathrm{L} \times \mathrm{T}$

$$
\begin{array}{ll} 
& =16 \mathrm{~m} \times 2 \mathrm{~m} \times 2,8 \mathrm{~m} \\
\text { Volume } & =180 \mathrm{~m}^{3} \\
\mathrm{Td} & =5 \text { menit }
\end{array}
$$

Perencanaan Ulang Dimensi Prasedimentasi IPAM Dago Pakar

$$
\begin{array}{ll}
\mathrm{Q} & =600 \mathrm{~L} / \mathrm{dtk} \\
\mathrm{Td} & =30 \text { menit }
\end{array}
$$

Volume $=600 \mathrm{~L} / \mathrm{dtk} \times 30$ menit $\times 60 \mathrm{dtk} /$ menit $=1.080 .000 \mathrm{~L}=1.080 \mathrm{~m}^{3}$

- Volume yang belum terpenuhi

$$
1.080 \mathrm{~m}^{3}-180 \mathrm{~m}^{3}=900 \mathrm{~m}^{3}
$$

- Lahan yang masih bisa dimanfaatkan adalah sebesar $10 \mathrm{~m}$

- Luas $=16 \mathrm{~m} \times 10 \mathrm{~m}$

$$
=160 \mathrm{~m}^{2}
$$

- Tinggi = Volume/Luas

$$
\begin{aligned}
& =900 \mathrm{~m}^{3} / 160 \mathrm{~m}^{2} \\
& =5,6 \mathrm{~m}
\end{aligned}
$$

Perhitungan di atas menyimpulkan bahwa dimensi $(\mathrm{P} \times \mathrm{L} \times \mathrm{T})$ baru bak prasedimentasi IPAM Dago Pakar adalah $16 \mathrm{~m} \times 10 \mathrm{~m} \times 5,6 \mathrm{~m}$.

\section{KapasitasRuang Lumpur}

Berdasarkan percobaan penyisihan partikel diskrit menggunakan kerucut Imhoff dengan waktu detensi 30 menit yang dilakukan di laboratoriumTeknik Lingkungan UNPAS, maka perhitungan kapasitas ruang lumpur untuk bak prasedimentasi adalah sebagai berikut :

Dari 1 liter air baku penyisihan yang didapat setelah 30 menit adalah $5 \mathrm{~mL} / 1000 \mathrm{~mL}$. Maka untuk debit air $600 \mathrm{~L} /$ dtktotal penyisihannya adalah $3.000 \mathrm{ml} / \mathrm{dtk}$. Untuk waktu detensi 30 menitmaka volume ruang lumpurnya adalah :

$=3000 \mathrm{ml} / \mathrm{dtk} \times 30$ menit $\times 60$ detik

$=5.400 .000 \mathrm{~mL}$

$=5,4 \mathrm{~m}^{3}$

Berdasarkan perhitungan di atas maka dapat terlihat bahwa volume ruang lumpur untuk waktu detensi 30 menit adalah $5,4 \mathrm{~m}^{3}$.

\section{Kesimpulan}

Studi mengenai strategi optimasi pemanfaatan sumber air Bantar Awi Sungai Cikapundung terhadap instalasi pengolahan Dago pakar menghasilkan beberapa kesimpulan, yaitu:

1) Debit air baku yang dipergunakan oleh IPAM Dago pakar sudah memenuhi SIPPA yang berlaku, yaitu $600 \mathrm{~L} / \mathrm{dtk}$,

2) 3 faktor yang paling mempengaruhi besar kecilnya debit aliran sungai Cikapundung, terutama di Kawasan Bantar Awi yaitu intensitas hujan sepanjang tahun, penggundulan hutan serta perubahan alih fungsi lahan.

3) Sumber air baku yang digunakanoleh IPAM Dago Pakar dalam keadaan tercemar, karenater dapat cukup banyak parameter yang tidak memenuhi baku mutu pada saat dilakukannya pemeriksaan terhadap kualitas air baku,

4) Secara keseluruhan kinerka IPAM Dago Pakar ini sudah cukup baik dilihat dari hasil pemeriksaan air hasil olahan yang dilakukan setiap harinya, meskipun begitu IPAM Dago Pakar ini membutuhkan beberapa perbaikan di 
beberapa unit, antara lain intake, sedimentasi dan filtrasi, kerusakan yang terjadi antara lain pada katup otomatisasi pembuangan lumpur pada unit sedimentasi, kebocoran pada penstock di unit filtrasi dan mechanical screen pada unit intake.

5) Pemeriksaan terhadap kualitas air olahan juga masih memenuhi standar baku mutu yang telah ditetapkan yaitu PERMENKES No. 492/MENKES/PER/ IV/ 2010.

6) Pada musim penghujan, proses backwash bisa dilakukan hingga 3-5×1 hari/unit untuk itu disarankan pihak PDAM membangun sebuah bak penampungan air hasil backwash agar dapat dipompakan kembali ke unit koagulasi untuk diolah kembali.

7) Perencanaan ulang bak prasedimentasi untuk mengatasi fluktuasi kekeruhan pada sumber air baku yang pada musim penghujan dapat melebihi 1000 NTU dan untuk meningkatkan waktu detensi yang belum memenuhi kriteria desain.

\section{Daftar Pustaka}

Anggraini, F. D., Samadi, \& Warnadi. (Sept 2013). Pengaruh Pertumbuhan Penduduk terhadap Kebutuhan Air Bersih di Pulau Panggang, Kelurahan Pulau Panggang, Kecamatan Pulau Seribu Utara, Provinsi DKI Jakarta. SPATIAL Wahana Komunikasi dan Informasi Geografi Vol. 12 No. 2 , 25-30.

Oktaviasari, S. A., \& Mashuri, M. (2016). Optimasi Parameter Proses Jar TestMenggunakan Metode Taguchidengan Pendekatan PCR-TOPSIS (Studi Kasus: PDAM Surya Sembada Kota Surabaya). Jurnal Sains dan Seni, Vol. 5 No. 2: 2337-3520. 